DOI https://doi.org/10.30525/978-9934-588-90-7-87

\title{
ИСПОЛЬЗОВАНИЕ АССОЦИАТИВНЫХ МЕТОДИК В ПРАКТИКЕ ПРЕПОДАВАНИЯ ИНОСТРАННЫХ ЯЗЫКОВ
}

\author{
Тарлева А. В. \\ кандидат филологических наук, \\ доцент кафедры языковой подготовки иностранных граждан
}

Мацапура Л. В.

кандидат филологических наук, преподаватель кафедры языковой подготовки иностранных граждан Харьковский национальный медицинский университет 2. Харьков, Украина

Различные методы, методики и приемы, включающие работу с ассоциациями, позволяют повысить эффективность работы в аудитории при изучении иностранных языков.

Применение ассоциативного метода Ричарда Аткинсона позволяет ускорить процесс запоминания слов. В его основе лежит идея построения логической связи между запоминаемым словом и словом родного языка по сходству в звучании этих слов. Идея разрабатывалась в 70-е годы прошлого века группой исследователей под руководством ученогопсихолога Р. Аткинсона. Метод способствует созданию прочных ассоциативных связей в сознании обучающихся, что позволяет сохранять образ и значение слова в памяти.

Слова-созвучия - так были названы сопоставляемые для запоминания лексемы - не должны были совпадать по значению. Их задачей было формирование образов, которые сохранялись в памяти и всплывали в момент использования.

Наиболее ярким примером подобной ассоциации при запоминании английских слов русскоговорящими выступает пара «look - лук». Сюжет-фраза, предложенный для примера, в этом случае мог звучать следующим образом: «Не могу смотреть, когда режут лук» [4].

Прием, позволяющий заметить сходство между словами разных языков, называется мнемотехникой. Связи, формируемые в процессе запоминания, чаще всего носят индивидуальный характер, хотя могут передавать и коллективный опыт, отражающий общие закономерности восприятия слов и понятий. 
Мнения об эффективности подобных методик неоднозначны. Как и любой другой метод, ассоциативный метод «работает» достаточно индивидуализировано, подходит не всем. И чаще всего в случаях, когда необходимый образ приходит неосознанно и является достаточно ярким, чтобы сохраниться в памяти.

Несколько примеров, которые можно предложить для запоминания слов, грамматических форм русского языка.

Графические ассоциации: последние буквы вопросов родительного падежа (кого? чего?) совпадают с последними буквами формы родительного падежа прилагательных единственного числа мужского и среднего рода (-ого; -его). Так же можно запомнить окончания вопросов и прилагательных в дательном (кому? чему?, - -ому, -ему), предложном (о ком? о чем? - -ом, -ем) падежах.

Лексические ассоциации: четвертый-четверг, пятый - пятница.

Лексико-синтаксические: совпадение значения глагольных приставок в глаголах движения и предлогов, которые с ними сочетаются: отойти от стола, дойти до остановки.

Когнитивные способности человека формировать связи между событиями работают и в обучении говорению на уроках иностранного языка.

Учащимся предлагается слово, вокруг которого записываются кольца ассоциаций. И если в первом кольце располагаются ассоциации с "прозрачным" смыслом, понятным окружающему большинству, то каждая последующая ассоциация приобретает все более завуалированное значение. К словам первого кольца, в свою очередь, также предлагаются ассоциации.

Учащиеся с удовольствием включаются в процесс, который увлекает их, поскольку предлагает цель, доступную для решения. На следующем этапе им необходимо объединить слова в предложения, используя, по заданию преподавателя, либо слова только первого круга, либо все слова, записанные на доске. На более высоком уровне владения языком в качестве основного задания предлагается составить связный рассказ с использованием разных слов.

Задача приобретает творческий характер, для еe решения привлекаются новые слова, которые должны быть оформлены в предложения по законам языка.

Рассказ записывается на изучаемом языке с использованием законов и закономерностей грамотного оформления фразы. Включаются механизмы моторной памяти. 
Ассоциации важны также для углубления знаний культурологического характера.

Сравнение данных ассоциативных словарей разных языков позволяет акцетировать внимание на объеме понятия. Среди ассоциаций встречаются такие, которые непонятны обучающимся и требуют разъяснения.

Слово в культуре включает целый пласт “сюжетов”, которые, разворачиваясь в процессе изучения, раскрывают перед учащимися «историю», выводят на уровни фольклора, фразеологии, авторской поэзии и прозы, что позволяет углубить знания об изучаемом языке и научиться работать со словарями, справочной, философской литературой.

Метод свободного ассоциативного эксперимента, который был заимствован из психологии, разработан и впервые применен Ф. Гальтоном в 19 веке, в наше время часто используется в сопоставительной лингвистике, в работах по лингвокультурологии, психолингвистике, когнитивной лингвистике, при описании концептуальной картины мира изучаемого языка.

Суть метода сводится к описанию реакций, которые возникают у людей на стимул, предложенный исследователем. Анализ возникающих ассоциаций приводит к очень интересным выводам, позволяет определить объем понятия, его историю, культурные связи, коннотативные и аксиологические характеристики.

Свободный ассоциативный эксперимент может быть прямым и обратным.

Прямой: ассоциации к слову. Обратный: определение стимула по набору ассоциаций.

И если обратный ассоциативный эксперимент позволяет определить общее в объеме понятия в сравниваемых языках, то прямой ассоциативный эксперимент, в первую очередь, выявляет разницу в семантике слова.

Особый интерес к такого рода экспериментам вызывает сравнительный аспект, когда применение методики позволяет углубить знания о культуре народа - носителя изучаемого языка - у изучающего этот язык.

\section{Литература:}

1. Гальтон Фрэнсис. Психометрические эксперименты. С. 149-162. (Francis Galton, Psychometric experiments. Brain, vol. 2, 1879). 
2. Горошко Е.И. Интегративная модель свободного ассоциативного эксперимента. Харьков, Москва: PA-Каравелла, 2001. URL: http://www.textology.ru/razdel.aspx?ID=38 (дата обращения 25.10.2020)

3. Стернин И.А. Психолингвистика и концептология. Bonpocbl психолингвистики. Научный журнал теоретических и прикладных исследований. 2007. № 5. С. 33-40.

4. Atkinson R.C., Raugh M.R. An application of the mnemonic keyword method to the acquisition of Russian vocabulary. Journal of Experimental Psychology: Human Learning and Memory. 1975.

DOI https://doi.org/10.30525/978-9934-588-90-7-88

\section{ПРИНЦИП ПРОФЕСІЙНОЇ МІЖКУЛЬТУРНОЇ СПРЯМОВАНОСТІ ПРИ НАВЧАННІ ЕSР}

\section{Трофименко А. 0.}

кандидат педагогічних наук, дочент кафедри іноземних мов

Кам'янець-Подільський національний університет імені Івана Огієнка м. Кам'янеиь-Подільський, Хмельницька область, Украйна

В останні роки Україна, включившись в процес активного економічного співробітництва із Заходом, водночас встала на шлях реформування сфери освіти. В українських вузах стали виникати нові відділення і факультети, які готують фахівців з таких спеціальностей, як зв'язку з громадськістю, державне управління, міжнародні відносини, міжнародне право, політологія і т. д.

Вступ світового співтовариства в еру інформаційної цивілізації визначає необхідність подолання комунікативних бар'єрів, якими $\epsilon$, зокрема, іноземні мови, тому в теорії і практиці сучасної освіти іншомовна професійна компетентність розглядається як найважливіша якість фахівця.

Використання інтерактивного підходу в навчанні ESP студентів $є$ виправданим і забезпечує хороші результати на увазі того, що успішне взаємодія в складних інтерактивних ситуаціях професійного спілкування багато в чому визначається вмінням налагодити міжособистісні відносини і залежить від готовності до неупередженого сприйняття партнера, усвідомлення етапів ситуації, стратегій і тактик кооперативної взаємодії, їх мовних маркерів, від знання специфіки професійної 